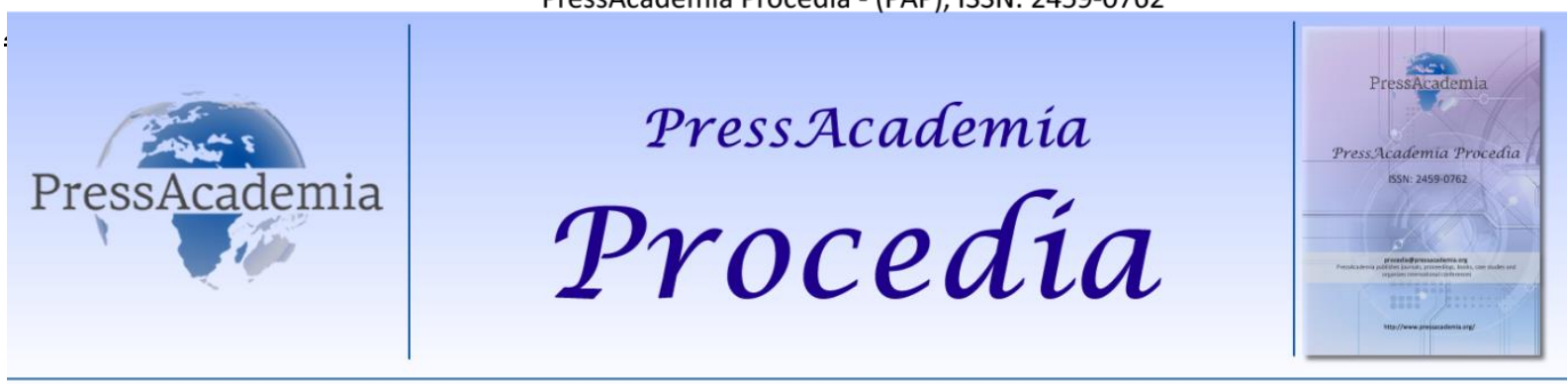

2nd World Conference on Technology, Innovation and Entrepreneurship

May 12-14, 2017, Istanbul, Turkey. Edited by Sefer Şener

\title{
AN ANALYSIS OF TURKEY'S EXPORT COMPETETIVENESS ACCORDING TO THE SITC TECHNOLOGY CLASSIFICATION
}

\author{
DOI: 10.17261/Pressacademia.2017.527 \\ PAP-WCTIE-V.4-2017(19)-p.129-133 \\ Kazim Saricoban ${ }^{1}$, Elif Kaya ${ }^{2}$ \\ ${ }^{1}$ Kilis 7 Aralik University, kazimsaricoban@hotmail.com \\ ${ }^{2}$ Kilis 7 Aralik University, elifk.7@hotmail.com
}

\begin{abstract}
The main purpose of this paper is to determine Turkey's export competitiveness in respect of SITC Technology Classification. The classification has five different categories of goods, namely, raw-material-intense, labour-intense, capital-intense, easy-to-imitate and hard-to-imitate. For analysis, Turkey's export data (US dollars) between 1996 and 2015 is used. Revealed Comparative Advantage (RCA) formula by Bela Balassa (1965) is taken as methodology to analyse. In compliance with Turkey's RCAs of the period, it is found out that Turkey has competitiveness (comparative advantages) on the export of labour intensive and capital intensive goods while it has competitiveness disadvantage on the raw-material intense, easy-to-imitate and hard-to-imitate goods which are research-based goods. It means the goods exported by Turkey is mostly production of labour intense technology, thus it demonstrates that the labour factor is the most significant production factors for Turkey. However, Turkey has disadvantage on easy-to-imitate and hard-to-imitate researchdevelopment-based goods strengthen by innovation and high value added products, which are commonly accepted as development indicators for countries.
\end{abstract}

Keywords: Export competitiveness, SITC, technology classification, Balassa Index, RCA JEL Codes: F14, F17

\section{INTRODUCTION}

It is important to determine export structure of countries in terms of their use of export policies. Especially competitiveness analysis in sectoral level has importance to obtain effective results from the right policies practise at right time. Although it seems to rise aggregate export, exports or competition policies in the sectors with no competitiveness embody negativity indeed. Supporting the sectors with insufficient knowledge and technology, weak R\&D, low-intense capital, and unskilled labour force will hamper effective use of scarce resources, thus it will have a negative influence on the aggregate export and competitiveness in long term. Such policy practises derived from sectoral analyses are going to be determining for the countries having voice in international environment as much as surviving in there in both economic and political dimensions.

This paper is largely based on analysis of determining Turkey's sectoral competitiveness. To do so, the SITC ${ }^{1}$ technological classification is used and Turkey's competitiveness is tried to be categorised according to five classifications. In the analysis, Turkey's exports data for 20 years from 1996 to 2015 is yielded from the UN Comtrade database.

\section{LITERATURE REVIEW}

There are few studies of Turkey's technological classification according to determining of sectoral competitiveness which uses various RCA indexes. Some of them are summarized as follows.

\footnotetext{
${ }^{1}$ Standard International Trade Classification; see https://unstats.un.org/unsd/cr/registry/regcst.asp?Cl=14 for further information.
} 
In 2003, Yılmaz examines the competitiveness and specialization on international trade level of Turkey, the five EUcandidate-countries (Bulgaria, Hungary, Romania, Poland, and Czech Republic), and that of the EU-15. His findings demonstrate that Turkey has competitiveness only in labour intensive sectors.

Erlat and Erlat (2005) try to find out Turkey's export competitiveness against EU-15 by using data between 1990 and 2000. According to the paper's results, while Turkey has competitiveness in the exports of raw materials and labour intensive goods, it has weak competitiveness in the exports of easy-to-imitate and hard-to-imitate oriented goods.

In 2007, Simsek et. al. analyse Turkey's competitiveness in the EU market between 1993 and 2006. For them, it also occurs that Turkey is competitive on raw materials and labour intensive goods exports whilst it partially has competitiveness on capital intensive goods; however, it has competitiveness disadvantage on the research-based goods exports.

In his comprehensive papers, Erkan (in 2011 and 2012) studies out similar results. In his first paper published in 2011, he uses foreign trade data from 1993 to 2009 to define sectoral competitiveness for Turkey and N-11. Akin to the previous studies, it suggests that Turkey has competitiveness on labour and capital intensive goods while it has competitiveness disadvantage in exports of easy-to-imitate and hard-to-imitate oriented goods. In oppose to previous studies he claims that Turkey has competitiveness disadvantage in raw materials as well.

In his second work in the field, in 2012, Erkan uses 1993-2010 data for Turkey and BRIC countries ${ }^{2}$ to measure competitiveness of them. The findings show that BRIC countries mostly have competitiveness on raw materials and labour intensive goods while Turkey is competitive largely in the exports of labour intensive and capital intensive goods.

\section{DATA AND METHODOLOGY}

The RCA index developed by Balassa (1965) is used to assess Turkey's competitiveness in respect of SITC technological classification. He formulates the index as follows (Balassa, 1965:99-123):

$$
\mathrm{RCA}=\frac{X_{k t}^{j} / X_{t}^{j}}{X_{k t}^{w} / X_{t}^{w}}
$$

Where $j$ stands for country, $t$ for time, $k$ for goods group/sector and $w$ for world/country groups. The numerator of the large fraction indicates the share of country j's exports of goods $k$ within its total exports in the term $t$. Likewise, the denominator shows the share of the world's exports of goods $k$ within its total exports in the term $t$. If RCA value is bigger than 1 , it means the country is specialized in that goods group/sector, that is to say, it has competitiveness advantages; if RCA smaller than 1, it means the country has no competitiveness in that goods group/sector, in other word, it has competitiveness disadvantages (Bojnec and Fertő, 2006:584; Khatibi, 2008:4; Nesterenko, 2006:6).

In the assessment of results, it is beneficiary to divide Balassa index in 4 groups for easier interpretation as follows (Hinloopen and Marrewijk, 2001:13):

$\begin{array}{lll}\text { Group-1 } \rightarrow 0<\mathrm{RCA} \leq 1 & \rightarrow & \text { Disadvantages, no competitiveness. } \\ \text { Group-2 } \rightarrow 1<\mathrm{RCA} \leq 2 & \rightarrow & \text { Weak competitiveness. } \\ \text { Group-3 } \rightarrow 2<\mathrm{RCA} \leq 4 & \rightarrow & \text { Medium advantage. } \\ \text { Group-4 } \rightarrow 4<\mathrm{RCA} & \rightarrow & \text { Strong competitiveness. }\end{array}$

In the study, arithmetic mean of the RCA coefficients is taken for years from 1996 to 2015. Meanwhile, trimmed mean, that is calculated by excluding the highest and the lowest values of the series in observation values, is measured for the series to obtain better outcomes.

The data set used in the analysis consists of Turkey's export numbers (\$) between 1996 and 2015. SITC technology classification comprises of five sectoral groups (labour intensive, raw material intensive, capital intensive, easy-to-imitate and hard-to-imitate) and each group includes goods group of SITC Rev. 3. In reference to this, goods groups of SITC Rev. 3 classification are illustrated as follows (Haufbauer and Chilas, 1974:3-38; Yılmaz, 2002:65 Buturac et. al., 2005:317; Utkulu and Seymen, 2004:3):

- $\quad$ Labour intensive goods: $26,61,63,64,65,66,69,81,82,83,84,85,89$

- Capital intensive goods: $1,35,53,55,62,67,68,78$

- Raw material intensive goods: 0, 21, 22, 23, 24, 25, 27, 28, 29, 32, 33, 34, 4, 56

- $\quad$ Easy-to-imitate (Easy imitable research-intensive goods): 51, 52, 54, 58, 59, 75, 76

\footnotetext{
${ }^{2}$ It stands for four countries, namely; Brazil, Russia, India and China.
} 
- Hard-to-imitate (Difficult imitable research-intensive goods): 57, 71, 72, 73, 74, 77, 79, 87, 88

\section{FINDINGS AND DISCUSSIONS}

Turkey's RCA findings are shown in the Table 1 according to the technological classification. Accordingly, Turkey has competitiveness in labour intensive and capital intensive goods exports in terms of trimmed mean values for both periods. For the labour intensive goods, it has medium advantage; for capital intensive goods, there is a weak advantage. Turkey, nevertheless, has disadvantage in the exports of raw materials, easy-to-imitate and hard-to-imitate goods.

Table 1: Turkey's RCAs according to SITC Technological Classification

\begin{tabular}{|l|c|c|c|c|}
\hline \multirow{2}{*}{ Goods } & \multicolumn{2}{|c|}{ RCAs } & \multirow{2}{*}{ Trimmed Mean } \\
\cline { 2 - 3 } & \multicolumn{2}{|c|}{ Mean } & \multirow{2}{*}{} \\
\cline { 2 - 3 } & $\mathbf{1 9 9 6 - 2 0 0 5}$ & $\mathbf{2 0 0 6 - 2 0 1 5}$ & 0.75 & Disadvantage \\
\hline Raw Metarial Int. & 0.87 & 0.66 & 2.29 & Medium Advantage \\
\hline Labour Intense & 2.44 & 2.14 & 1.47 & Weak Advantage \\
\hline Capital Intense & 1.24 & 1.70 & 0.33 & Disadvantage \\
\hline Easy-to-imitate & 0.33 & 0.32 & 0.54 & Disadvantage \\
\hline Hard-to-imitate & 0.43 & 0.64 & & \\
\hline
\end{tabular}

Obtained trimmed mean RCA values can be found in Graph 1. According to findings, it can be appropriate to say that Turkey is mostly exporting labour intensive goods. Thus, labour is a significant production factor for Turkey to keep exporting. However, Turkey has disadvantage on exports of innovation and R\&D oriented high-tech goods and high added value products which are one of the development indicators.

\section{Graph 1: Turkey's trimmed-mean-RCAs according to SITC Technological Classification (1996-2015)}

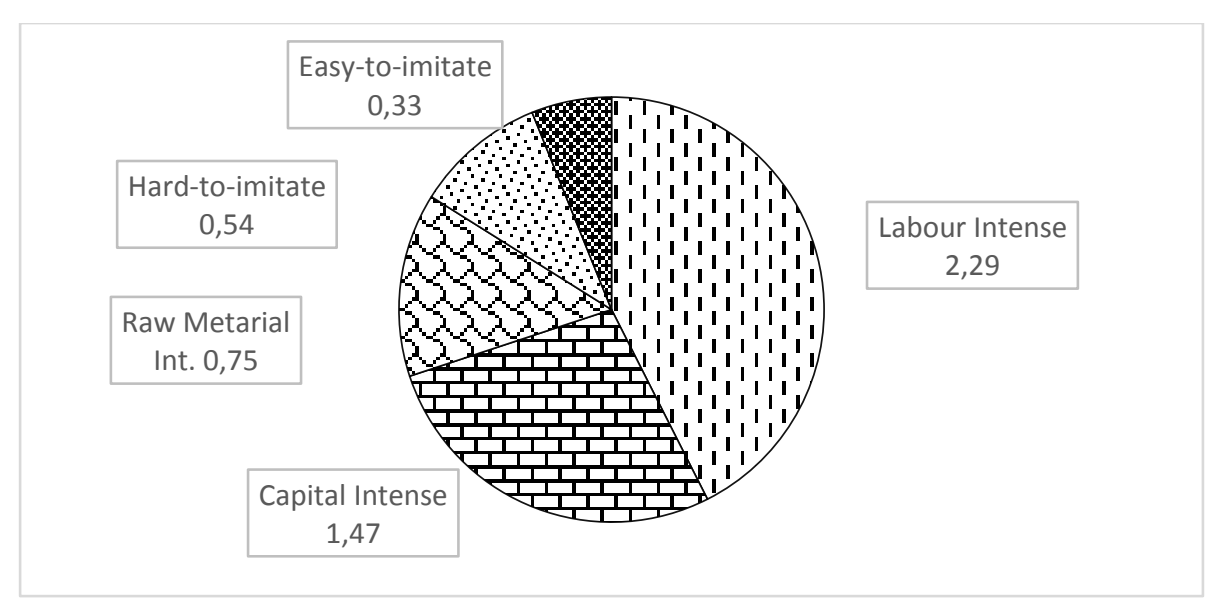

In the Table 2, RCA values are compared per two periods; first is between 1966 and 2005 and second is from 2006 to 2015. For whole course (1996-2015), also trimmed mean is measured to see how the values has changed in time and compare general mean to the first and the second period's. Changes between the periods and comparison with the general can be summarized as follows;

- In the raw materials exports, Turkey's RCA value decreased between the first period and the second from 0.87 to 0.66 respectively. It means Turkey lost its competitiveness advantage in second period.

- For labour intensive goods, RCA value which was 2.44 in the first period decline to 2.14 in the second period.

- Nonetheless, the RCA value for the country's exports of capital intensive goods rose to 1.70 in the second term from 1.24 in the first term. This shows Turkey's competitiveness in the mentioned group of product's exports.

- When looking at the RCA values of easy-to-imitate oriented goods, disadvantage that the country has on this group of goods was not changed.

- For the hard to imitate goods exports, even though there is competitiveness disadvantage in the first term, in the second term it seems there is a slight rise in competitiveness. 
Table 2: Comparison of Turkey's RCAs

\begin{tabular}{|l|c|c|c|}
\hline & $\mathbf{1 9 9 6 - 2 0 0 5}$ & $\mathbf{2 0 0 6 - 2 0 1 5}$ & $\mathbf{1 9 9 6 - 2 0 1 5}$ Trimmed Mean \\
\hline Raw Material Int. & 0,87 & 0,66 & 0,75 \\
\hline Labour Intense & 2,44 & 2,14 & 2,29 \\
\hline Capital Intense & 1,24 & 1,70 & 1,47 \\
\hline Easy-to-imitate & 0,33 & 0,32 & 0,33 \\
\hline Hard-to-imitate & 0,43 & 0,64 & 0,54 \\
\hline
\end{tabular}

According to the technological classification, changes in Turkey's RCA values from 1996 to 2015 is demonstrated in the Table 3. In this table, it can be seen that Turkey has RCA values bigger than 1 in labour intensive and capital intensive goods exports, thus it is implied that the country has competitiveness in those sectors. Having said that, Turkey has competitiveness advantage between 1996 and 1999 in raw materials exports, yet, after 2000, it lost this advantage. Turkey, in the exports of easy-to-imitate and hard-to-imitate goods which include innovation and R\&D oriented technological products and goods with high added value, has perpetuated its situation of being disadvantaged. As it is mentioned before, however, it is remarkable to see that the RCA values of hard-to-imitate goods that is research oriented has increased in the second term.

Table 3: Turkey's RCA Values Change in Years

\begin{tabular}{|c|c|c|c|c|c|c|c|c|c|c|}
\hline Goods $/ 1^{\text {st }}$ period & 1996 & 1997 & 1998 & 1999 & 2000 & 2001 & 2002 & 2003 & 2004 & 2005 \\
\hline Raw Material Int. & 1,1 & 1,2 & 1,2 & 1,0 & 0,7 & 0,8 & 0,7 & 0,7 & 0,6 & 0,7 \\
\hline Labour Intense & 2,4 & 2,4 & 2,5 & 2,5 & 2,7 & 2,4 & 2,5 & 2,5 & 2,3 & 2,3 \\
\hline Capital Intense & 1,1 & 1,1 & 0,9 & 1,1 & 1,2 & 1,3 & 1,3 & 1,3 & 1,6 & 1,5 \\
\hline Easy-to-imitate & 0,2 & 0,3 & 0,3 & 0,3 & 0,3 & 0,3 & 0,4 & 0,4 & 0,4 & 0,4 \\
\hline Hard-to-imitate & 0,3 & 0,3 & 0,3 & 0,4 & 0,5 & 0,5 & 0,4 & 0,5 & 0,5 & 0,5 \\
\hline Goods $/ 2^{\text {nd }}$ period & 2006 & 2007 & 2008 & 2009 & 2010 & 2011 & 2012 & 2013 & 2014 & 2015 \\
\hline Raw Material Int. & 0,6 & 0,7 & 0,6 & 0,7 & 0,7 & 0,7 & 0,6 & 0,7 & 0,7 & 0,8 \\
\hline Labour Intense & 2,2 & 2,1 & 2,0 & 2,1 & 2,2 & 2,2 & 2,1 & 2,2 & 2,2 & 2,0 \\
\hline Capital Intense & 1,6 & 1,6 & 1,9 & 1,8 & 1,8 & 1,8 & 1,6 & 1,7 & 1,6 & 1,5 \\
\hline Easy-to-imitate & 0,4 & 0,3 & 0,3 & 0,3 & 0,3 & 0,3 & 0,3 & 0,3 & 0,3 & 0,3 \\
\hline Hard-to-imitate & 0,6 & 0,6 & 0,6 & 0,6 & 0,6 & 0,7 & 0,6 & 0,7 & 0,7 & 0,6 \\
\hline
\end{tabular}

\section{CONCLUSION}

According to the SITC technological classification, in the determining of Turkey's competitiveness in the exports of goods within the five categories, namely, raw materials, labour intensive, capital intensive, easy-to-imitate and hard-to-imitate, it is concluded as follows;

- The country has medium competitiveness in the labour intensive goods and weak competitiveness in the capital intensive goods.

- It is disadvantaged in the exports of the rest (raw materials, easy-to-imitate and hard-to-imitate goods).

As a result of the analysis, it can be said that Turkey's export structure mostly consists of labour intensive products. Therefore, we may claim that the most important production factor for Turkey is labour. In addition, as one of the development indicators for countries, in the exports of easy-to-imitate and hard-to-imitate goods that involve innovation and R\&D oriented goods with high added value, Turkey has disadvantage for all years between 1996 and 2015. It can also be stated that the conclusion of this paper shows similarity with the previous studies in the literature.

The way of rising trade performance for a country is firstly specialization in its exports or to define what product groups or/and sectors it has competitiveness in. Then, the country should conduct policies to support these product groups or/and sectors. In that certain point, Turkey's backup over the labour intensive and capital intensive sectors in the short run will play an important role in the country's trade performance. However, specifically in the support of labour intensive sectors would not improve the performance as much as it is desired as the sector involves goods with quite low added values. For this reason, Turkey should give sufficient importance to R\&D investments and innovations in the long run in order to reach the high performance of trade. To do so, as Sener (2013) argues in his work, Turkey has to take account to advance "[its] 
macroeconomic environment, higher education and training, innovation, technological readiness, labour market efficiency, institutions, goods market efficiency". Only if it follows this path, Turkey will be able to produce high value added research base goods, so that having competitiveness in international level and raising national income.

\section{REFERENCES}

Balassa, B. (1965). "Trade Liberalization and Revealed Comparative Advantage". The Manchester School of Economic and Social Studies. 33(2). May 1965. pp:99-123.

Bojnec, Š. and Ferto, I. (2006). "Does Comparative Advantages in Agri-Food Trade Matter for Multifunctional Rural Development: The Case of Hungary and Slovenia". Journal of Central European Agriculture. 7(3). pp:583-586.

Buturac, G., Lovrincevik, Z. and Teodorovic, I. (2005). "Comparison of the Structure and Development of International Trade within the Framework of EU Enlargement: The Case of Croatia". Proceedings: 65th Anniversary Conference of the Institute of Economics. Zagreb; November 18 - 19. 2004. ISBN 9536030292-2005. p: 315-342.

Erkan, B. (2011). "SITC Teknoloji Sınıflandırmasına İlişkin Açıklanmış Karşılaştırmalı Üstünlüklerin Belirlenmesi: Türkiye ve Diğer N-11 Ülkelerinin Karşılaştırılması”. Finans Politik \& Ekonomik Yorumlar. 48(558). pp: 35-48.

Erkan, B. (2012). "BRIC Ülkeleri ve Türkiye'nin İhracat Uzmanlaşma ve Rekabet Düzeylerinin Karşılaştırmalı Analizi”. Ekonomik ve Sosyal Araştırmalar Dergisi. 8(1). Bahar-2012. pp:101-131.

Erlat, G. and Erlart, H. (2005). "Do Turkish Exports Have Comparatıve Advantage with Respect to The European Union Market, 1990-2000". Topics in Middle Eastern and North African Economies. Vol:7. September 2005. pp: 1-17.

Hinloopen, J. and Marrewijk, C. V. (2001). "On the empirical distribution of the Balassa index" Review of World Economics / Weltwirtschaftliches Archiv 137: s:1-35.

Haufbauer C.G. and Chilas J.C. (1974). "Specialisation by Industrial Countries: Extent and consequences, in the International Division of Labour: Problems and Perspectives". Edited by H. Giersch. Institut für Weltwirtschaft. Tübingen: Mohr, 1974.

Khatibi, A. (2008). “Kazakhstan's Revealed Comparative Advantage Vis-À-Vis the EU-27", European Centre for International Political Economy (ECIPE). Working Paper, No: 03/2008, pp:1-12.

Nesterenko, O. (2006). "Competitiveness of Ukrainian Products". Master of Arts in Economics. National University "Kyiv-Mohyla Academy" Economics Education and Research Consortium Master's Program in Economics. pp:1-49.

Sener, S. (2013). "The Competitiveness of Turkish Economy Within the Scope of WEF Global Competitiveness Index". Procedia - Social and Behavioral Sciences 75, pp:453-464. Doi: 10.1016/j.sbspro.2013.04.049.

Şimşek, N., Seymen, D. and Utkulu, U. (2007). "Turkey's Competitiveness in the EU Market: A Comparison of Different Trade Measures". In European Trade Study Group (ETSG) 9th Annual Conference 2007. pp: 1-44.

Utkulu, U. and Seymen, D. (2004). "Revealed Comparative Advantage and Competitiveness: Evidence for Turkey vis-à-vis the EU/15". In European Trade Study Group 6th Annual Conference. ETSG. September 2004. pp:1-26.

Yilmaz, B. (2002), "The Role of Trade Strategies for Economic Development: A Comparison of Foreign Trade Between Turkey and South Korea". Russian and East European Finance and Trade, 38(2). March-April 2002. pp. 59-78.

Yilmaz, B. (2003). "Turkey's Competitiveness in The European Union: A Comparison with Five Candidate Countries - Bulgaria, The Czech Republic, Hungary, Poland, Romania - and The EU15". The East Enlargement of the Eurozone. Ezonplus. Working Paper, No:12. February 2003. 